University of Nebraska - Lincoln

DigitalCommons@University of Nebraska - Lincoln

Faculty Publications from the Harold W. Manter Laboratory of Parasitology

$12-1962$

\title{
Helminths of the Shrew-Mole Neürotrichus gibbsii (Baird) in Oregon
}

Robert L. Rausch

University of Washington, rausch@uw.edu

Follow this and additional works at: https://digitalcommons.unl.edu/parasitologyfacpubs

Part of the Parasitology Commons

Rausch, Robert L., "Helminths of the Shrew-Mole Neürotrichus gibbsii (Baird) in Oregon" (1962). Faculty Publications from the Harold W. Manter Laboratory of Parasitology. 349.

https://digitalcommons.unl.edu/parasitologyfacpubs/349

This Article is brought to you for free and open access by the Parasitology, Harold W. Manter Laboratory of at DigitalCommons@University of Nebraska - Lincoln. It has been accepted for inclusion in Faculty Publications from the Harold W. Manter Laboratory of Parasitology by an authorized administrator of DigitalCommons@University of Nebraska - Lincoln. 
The Journal of Parasitology

Vol. 48, No. 6, December 1962, p. 813-817

\title{
HELMINTHS OF THE SHREW-MOLE NEÜROTRICHUS GIBBSII (BAIRD) IN OREGON
}

\author{
Robert L. Rausch \\ Arctic Health Research Center, Public Health Service, U. S. Department of Health, \\ Education, and Welfare, Anchorage, Alaska
}

\begin{abstract}
Helminths of the shrew-mole from Oregon are described. They include a cestode Hymenolepis neürotrichi sp. n., a trematode Microphallus aspalacis sp. $\mathrm{n}$., and the thirdstage larva of an undetermined species of Porrocaecum (nematode), probably $P$. depressum (Zeder, 1800), or P. angusticolle (Molin, 1860). Preserved viscera of ten animals were examined. Three were infected.
\end{abstract}

The parasites of the North American shrewmole Neürotrichus gibbsii (Baird), an insectivore found only in the humid coastal region of the Pacific northwest, were reported by Dalquest and Orcutt (1942) to include a cestode Hymenolepis sp. and an unidentified nematode. Theirs is the only published record of helminths from this mammal. Over a period of years Dr. Murray L. Johnson, Curator of Mammals, University of Puget Sound, has provided me with material that made possible a further study of the parasites of shrew-moles. The preserved viscera of ten animals were sent by Dr. Johnson, who had in each case opened the intestine and preserved its contents in formalin, thereby insuring the rapid fixation of any helminths present. The examination of the material disclosed that three animals were infected, and, in the aggregate, helminths representing three species were collected. The findings are reported here. (All measurements are in millimeters.)

\section{Hymenolepis neürotrichi $\mathrm{sp} . \mathrm{n}$. (figs. 1 to 3 )}

Five specimens of this cestode were found in a shrew-mole collected on 10 April 1957, near Molalla, Oregon. These were stained in Semichon's acetic carmine and mounted in toto.

Diagnosis: Strobila up to 50 long; maximum width, attained usually in gravid segments, about 2 . Immature portion of strobila much attenuated; strobilar margins serrate. All segments wider than long; length/width ratio of mature segments about $1: 5$, with relative length increasing toward posterior portion of strobila until ratio of about $1: 2$ is attained in gravid segments. Weakly developed

Received for publication 11 June 1962. scolex about 0.160 in greatest width; unarmed suckers about 0.075 in diameter. Rostellum not observed. Genital pores unilateral, dextral; situated just anterior to middle of segmental margin. Elongate cirrus sac, measuring 0.090 to 0.110 long by 0.023 to 0.027 wide (avg 0.100 by 0.025 ) in mature segments, usually extends mediad beyond ventral longitudinal excretory canal. Both internal and external seminal vesicles well developed. Cirrus spinose. Testes more or less ovoid, measuring 0.068 to 0.107 long by 0.049 to 0.065 wide in mature segments. Testes arranged in triangle, 1 poral and 2 aporal; of latter, one is situated anterolateral to other and may extend anteriad nearly to level of anterior margin of ovary. Ovary lobed, situated near middle of segment; it overlaps anterior portion of poral testis and extends anteriad to segmental margin. Vagina opens in genital atrium just posterior to opening of male duct. Seminal receptacle small. Vitelline gland more or less ovoid in shape, slightly lobed or entire and situated near midline at posterior margin of segment. Early uterus reticulate, enlarging gradually to fill gravid segment within limits of ventral longitudinal excretory canals. Embryophores fusiform with pointed ends, measuring 0.043 to 0.048 long by 0.015 to 0.018 wide (avg 0.045 by 0.017 ). Oncosphere ovoid, measuring about 0.027 by 0.014 .

Host: Neürotrichus gibbsii (Baird).

Type locality: Seven miles south of Molalla, Oregon.

Habitat: Small intestine.

Type: Two slides containing an entire cestode have been deposited in the Helminthological Collection of the U.S.N.M. No. 59813.

Discussion: Although several attempts have been made to revise the classification of hymenolepidid cestodes, no acceptable system has been thus far devised. The species in mammals have been considered recently by Spasskii (1954) and by Yamaguti (1959), both of whom established several new genera for species of Hymenolepis s. 1. The classifica- 

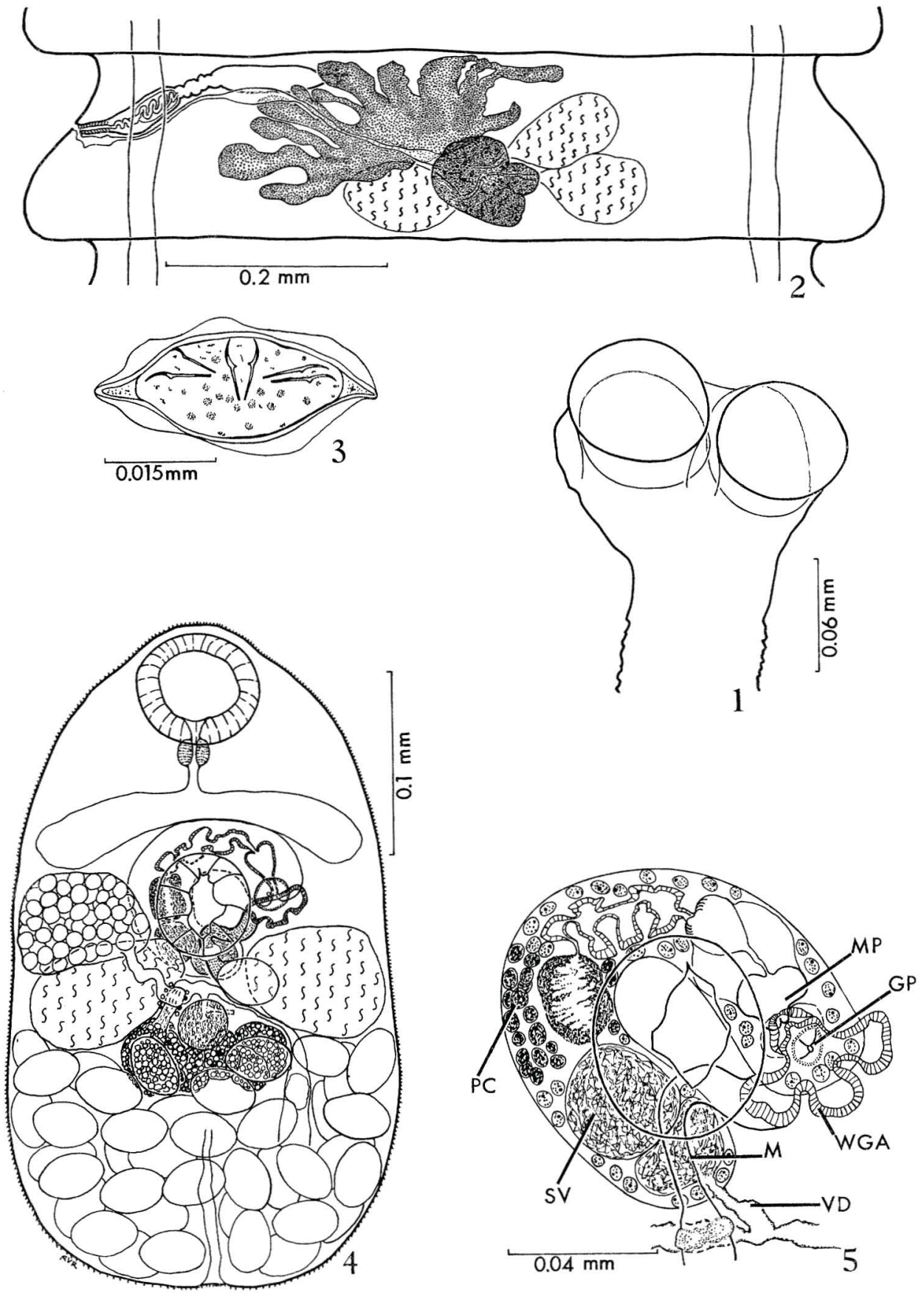

Plate I

FIGURE 1. Hymenolepis neürotrichi sp. n., scolex.

FIGURE 2. H. neürotrichi, mature segment, ventral view.

Figure 3. H. neürotrichi, embryophore with oncosphere.

Figure 4. Microphallus aspalacis sp. n., entire trematode, ventral view.

Figure 5. M. aspalacis, details of genital ducts.

$\mathrm{MP}=$ male papilla; $\mathrm{GP}=$ genital pore; $\mathrm{WGA}=$ wall of genital atrium; $\mathrm{M}=$ metraterm; $\mathrm{VD}=\mathrm{vas}$ deferens; $\mathrm{SV}=$ seminal vesicle; $\mathrm{PC}=$ prostate cells. 
tion proposed by Spasskii has already been critically reviewed by Rybicka (1959), whose criticisms apply as well to Yamaguti's system. Spasskii (1961) has recently undertaken a new revision of the Hymenolepididae which includes an examination of the classification proposed by Yamaguti. Since the cestode described here conforms in morphological characteristics to the genus Hymenolepis as defined both by Spasskii (1954) and by Yamaguti (1959), further discussion of its generic position is unnecessary.

The many species of hymenolepidid cestodes occurring in insectivores demonstrate a high degree of host-group, or phylogenetic, specificity (Voge and Rausch, 1955). Members of different families of insectivores apparently rarely share species of cestodes, and, therefore, it might be expected that species of Hymenolepis most closely related to $H$. neürotrichi would be found in mammals of the family Talpidae. Two species of Hymenolepis lacking an armed rostellum have been described from moles: H. scalopi Schultz, 1939, from the North American Scalopus aquaticus (Linnaeus), and $H$. peipingensis $\mathrm{Hsü,} 1935$, from Talpa sp., in China. The species described here is similar morphologically to both.

Comparison of $H$. neürotrich $i$ with $H$. scalopi discloses the following differences: H. scalopi is a much larger cestode, with segments that are very short in proportion to their width (ratio $1: 15$ to $1: 20$ ). In $H$. scalopi the cirrus sac does not reach the ventral longitudinal excretory canal, the uterus is of different form, and, apparently, the embryophore is spherical rather than fusiform. H. peipingensis is a somewhat larger cestode than $H$. neürotrichi; the length/width ratio (ca. 1:6) of its mature segments is similar to that of the latter, but there does not appear to be a comparable relative increase in length of the gravid segments. The cirrus sac may reach the lateral margin of the ventral longitudinal excretory canal in $H$. peipingensis but does not extend farther mediad. The cirrus of the latter was described as unarmed, and the testes are usually arranged in a transverse row. The uterus extends beyond the ventral longitudinal excretory canals in gravid segments of $H$. peipingensis. Fully developed eggs have not been described.
Two additional species from moles, Staphylocystis (= Hymenolepis) bacillaris (Goeze, 1782 ) and Rodentolepis (= Hymenolepis) olsoni (Neiland and Senger, 1952), possess an armed rostellum. H. neürotrichi does not resemble any of the species that occur in shrews (Soricidae), but it is rather similar to Rodentolepis erinacei (Gmelin, 1790), which is found in hedgehogs (Erinaceidae). It can be distinguished from the latter by differences in the relative proportions of various organs, including the cirrus sac which in $H$. erinacei extends across one-third or more of the width of the mature segment (von Janicki, 1906).

\section{Microphallus aspalacis $\mathrm{sp} . \mathrm{n}$}

(figs. 4 to 5 )

The intestine of a shrew-mole collected on the Miami River, Oregon, 2 July 1957, contained about 90 small trematodes referred to the genus Microphallus Ward, 1901. Various stains were used for specimens mounted in toto, and specimens cleared in glycerin were studied; serial sections also were prepared in order to work out the relationships of the genital organs.

Diagnosis: Body ovate to pyriform, measuring 0.300 to 0.385 long (avg 0.340 ) by 0.162 to 0.251 wide. Greatest width usually posterior to level of acetabulum. Entire integument covered by minute spines, about 0.001 apart, arranged in parallel rows. Spherical oral sucker, subterminal, measures 0.062 to 0.073 (avg 0.066 ) in greatest diameter. Prepharynx short; globular pharynx well developed. Esophagus relatively short, joining intestinal ceca just anterior to acetabulum; ceca short and widely divergent, extending beyond lateral margins of acetabulum. Spherical acetabulum situated at or just anterior to middle of body; it measures 0.045 to 0.070 (avg 0.056) in greatest diameter. Ovoid testes opposite, symmetrical, situated in posterior half of body; they measure 0.052 to 0.081 in length. Seminal vesicle large, connected by well-formed duct to thick, papillalike copulatory organ opening into anterior wall of genital atrium. Latter complex, with prostate cells, surrounded by thin membrane. Genital pore, either dextral or sinistral (ca. $1: 1$ ratio) opens anterolateral or lateral to acetabulum; genital atrium relatively large with thick, folded walls. Ovoid ovary, dextral or sinistral, situated posterolateral to acetabulum, measures 0.045 to 0.073 in greatest diameter. Egg-filled uterus occupies portion of body posterior to testes; thick-walled metraterm opens in posterior wall of genital atrium. Vitelline follicles comprise usually bilobed mass median in position immediately posterior to testes. Seminal receptacle well developed; Laurer's canal present. Operculated eggs relatively large, meas- 
uring 0.036 to 0.042 long by 0.023 to 0.025 wide (avg 0.040 by 0.024 ); up to 60 eggs observed in single trematode.

Host: Neürotrichus gibbsii.

Type locality: Miami River, Oregon.

Habitat: Small intestine.

Type: A slide containing a trematode mounted in toto has been deposited in the Helminthological Collection of the U.S.N.M., No. 59814.

Discussion: It is evident from a review of the literature that taxonomists disagree as to criteria that would serve to delineate microphalline genera. Biguet et al. (1958) revised the subfamily Microphallinae, concluding that only four genera should be distinguished: Levinseniella Stiles and Hassall, 1901; Spiculotrema Belopol'skaia, 1949; Microphallus Ward, 1901; and Endocotyle Belopol'skaia, 1952. In addition to the latter, Yamaguti (1958) restored several previously suppressed genera, evidently attaching considerable significance to host occurrence. It appears that the concept of Biguet et al. is the more acceptable, at least until the knowledge of these trematodes has been supplemented by much new information. As recently pointed out by Stunkard (1960), the limits of Microphallus are especially uncertain.

The trematode described here seems best assigned to the genus Microphallus, as defined by Biguet et al. (1958), although the erection of a new genus might be justified. Comparisons have been made directly with $M$. pirum (Afanas'ev, 1941) [considered by Biguet et al. to be conspecific with M. excellens (Nicoll, 1907) ], M. opacus (Ward, 1894), and specimens reported by the writer as Microphallus sp. (Rausch, 1946), and it is concluded that the observed morphological differences are less than generic. Biguet et al. admit that the seminal vesicle and prostate may be enclosed by a "très mince membrane limitante," as appears to be the case in the present species. Moreover, the details of the copulatory organ have not been described in sufficient detail for many of the 21 species of Microphallus recognized by Biguet et al. More important is the fact that the vitellaria in the new species do not form two discrete masses but rather are confluent with a tendency toward a bilobed arrangement. For the time, this might be regarded as a modification of the typical microphallid form.
M. aspalacis is immediately separable from its congeners by the unique arrangement of the vitellaria. It can also be distinguished by differences in proportions of various organs and by size of the egg. The systematic position of this trematode may be subject to revision with refinement of the taxonomy of the group of species with which it is placed.

$M$. gracilis Baer, 1943, is the only species of this genus heretofore recorded from insectivores, having been described from a watershrew Neomys fodiens (Schreber). Biguet et al. (1958) considered $M$. gracilis to be probably conspecific with $M$. opacus, but there appears to be insufficient evidence for this conclusion.

\section{Porrocaecum sp.}

A single, encysted nematode, identified as a third-stage larva of Porrocaecum sp., was found in the animal from the Miami River locality. The species represented is probably either $P$. depressum (Zeder, 1800) or $P$. angusticolle (Molin, 1860), the adults of which occur in owls and hawks.

According to Dalquest and Orcutt (1942), shrew-moles feed largely in runways under decaying litter. On ecological grounds they might be expected to harbor helminths of species different from those in the burrowing moles (Scapanus) with which they are sympatric.

\section{ACKNOWLEDGMENT}

The assistance of Dr. Murray L. Johnson in making this material available is gratefully acknowledged.

LITERATURE CITEN)

Biguet, J., S. Deblock, And A. Capron. 1958. Contribution à la connaissance des Microphallidae Travassos, 1920 (Trematoda). II. Ann. Parasit. 33: 396-444.

Dalquest, W. W., and D. R. OrCutt. 1942. The biology of the least shrew-mole, Neurotrichus gibbsii minor. Am. Midland Nat. 27: 387-401.

Rausch, R. 1946. The raccoon, a new host for Microphallus sp., with additional notes on M. ovatus from turtles. J. Parasit. 32: 208209.

RybickA, K. 1959. Some remarks on the classification of the family Hymenolepididae Fuhrmann, 1907 (Cestoda). Acta Parasit. Polonica 7: 499-520.

SpasskII, A. A. 1954. Klassifikatsiia gimenolepidid mlekopitaiushchikh. Trudy gel'mint. lab., Akad. Nauk SSSR 7: 120-167. 
1961. Breve revisione di Hymenolepididae. Parte Prima; Parte Seconda. Parassitologia 3: 159-198.

Stunkard, H. W. 1960. Problems of generic and specific determination in digenetic trematodes with special reference to the genus Microphallus Ward, 1901. Lib. Homenaje Dr. Eduardo Caballero y C. Mexico, D. F., p. 299 309.

Voge, M., and R. Rausch. 1955. Occurrence and distribution of hymenolepidid cestodes in shrews. J. Parasit. 41: 566-574.

von JanickI, C. 1906. Studien an Säugetiercestoden. Z. Wiss. Zool. 81: 505-597.

Yamaguti, S. 1958. Systema helminthum. The digenetic trematodes of vertebrates-Part I. Vol. I. Interscience Publishers, N. Y.

1959. Systema helminthum. The cestodes of vertebrates. Vol. II. Interscience Publishers, N. Y. 